\title{
Water-use characteristics of Palmiet (Prionium serratum), an endemic South African wetland plant
}

\author{
AJ Rebelo', C Jarmain ${ }^{2}$, KJ Esler ${ }^{1,3}$, RM Cowling $^{4}$ and DC Le Maitre ${ }^{5}$ \\ 'Department of Conservation Ecology and Entomology, Stellenbosch University, Private Bag X1, Matieland, 7600, South Africa \\ ${ }^{2}$ Centre for Geographical Analysis, Stellenbosch University, Private Bag X1, Matieland, 7600, South Africa \\ ${ }^{3}$ Centre for Invasion Biology (C.I.B), Stellenbosch University, Private Bag X1, Matieland, 7600, South Africa \\ ${ }^{4}$ Department of Botany, Nelson Mandela University, PO Box 77000, Port Elizabeth, 6031, South Africa \\ ${ }^{5}$ Natural Resources and the Environment, CSIR, PO Box 320, Stellenbosch, 7599, South Africa
}

Palmiet, Prionium serratum, is an endemic wetland plant which dominates oligotrophic wetlands throughout the Cape Floristic Region, South Africa. Palmiet is often perceived as undesirable by landowners, in part because it is thought to have high water-use, although little is known about the water-use of this important wetland species. We estimated the water-use dynamics of Palmiet at the leaf scale, using stomatal conductance measurements, and at the wetland scale, by modelling evapotranspiration using remote sensing and an energy-balance model. Factors that influenced Palmiet water-use were also considered, and seasonal variations were analysed. The aim was to estimate Palmiet wetland water-use, and to develop a set of crop factors $\left(K_{c}\right)$ for use in hydrological modelling of catchments containing Palmiet wetlands. Results show that Palmiet has a comparatively low stomatal conductance (11-152 $\left.\mathrm{mmol} \cdot \mathrm{m}^{-2} \cdot \mathrm{s}^{-1}\right)$, which was lower in summer than winter, and moderate evapotranspiration for a riparian species (1 $220 \mathrm{~mm} \cdot \mathrm{a}^{-1}$ compared to a local reference evapotranspiration of $1302 \mathrm{~mm} \cdot \mathrm{a}^{-1}$ and A-Pan evaporation of $2809 \mathrm{~mm} \cdot \mathrm{a}^{-1}$ ), which was higher in summer (more energy to drive evapotranspiration and higher vapour pressure deficits). Morphological and physiological adaptations to nutrient poverty or periodic drought are suggested theories which may explain the controls on transpiration for Palmiet.

\section{INTRODUCTION}

Palmiet (Prionium serratum, Thurniaceae) is a common and prominent riparian wetland plant, endemic to river floodplains and fringes from Gifberg in the Western Cape, through the Eastern Cape to southern KwaZulu-Natal, South Africa (Boucher and Withers, 2004). Palmiet grows in dense stands of what appear to be separate plants but are often clonal systems (Boucher and Withers, 2004). These Palmiet wetlands are typically underlain by peat and accumulated sediments, built up over thousands of years (Haigh et al., 2002). Palmiet grows throughout the year, with flowering in spring and summer and fruit appearing in March (Boucher and Withers, 2004). Palmiet is intolerant of saline water and full shade, is fire adapted, and characterizes oligotrophic rivers and wetlands (Boucher and Withers, 2004). Palmiet is perceived by many landowners to be a nuisance, causing blockages in rivers and depletion of water resources, as it is thought to be a high water-user (Rebelo, 2012). Palmiet is therefore often removed to 'unblock the river' (Rebelo, 2012) or so that floodplain sediments can be cultivated.

Fynbos is the main vegetation type in which Palmiet wetlands occur, and, similarly to other Mediterranean-climate vegetation, Fynbos species tend to have conservative water-use with relatively low stomatal conductance and photosynthetic capacity (Von Willert et al., 1989; Mooney et al., 1983; Dzikiti et al., 2014; Meijninger and Jarmain, 2014). However, Fynbos riparian plants with permanent access to water in the root zone generally have higher evapotranspiration rates than their terrestrial counterparts, though not as high as invasive alien riparian trees (Everson et al., 1998; Scott, 1999; Dye et al., 2001; Everson et al., 2007; Everson et al., 2009; Clulow, 2011). The limited research conducted on South African wetlands has shown that wetland species (e.g. reeds: Phragmites mauritianus) are generally high water-users (Seyhan et al., 1983; Birkhead et al., 1997; Everson et al., 2001; Dye et al., 2008; Clulow et al., 2012).

There have been many studies internationally attempting to estimate the water-savings of clearing invasive alien trees with concomitant recovery of indigenous species (Doody et al., 2011; Doody et al., 2014; Le Maitre et al., 2016). There have also been many studies and much debate about wetland evapotranspiration globally, and whether it is similar, lower, or higher than evaporation from an open water surface (Mohamed et al., 2012). The pan coefficient (the ratio of mean evapotranspiration to mean pan evaporation) has been a useful technique to compare potential water savings across different climates (Mohamed et al., 2012; Doody et al. 2014). In a review of selected wetlands around the globe, the mean \pm standard deviation of pan coefficients was $0.87 \pm 0.26$, suggesting that most wetlands markedly reduce evaporation efficiency compared to open water (Mohamed et al., 2012). There has been very little research on the water-use of wetlands in South Africa, presenting a knowledge gap, especially for the parametrisation of hydrological models in studies which seek to compare scenarios of invasion in wetlands or riparian zones (Rebelo et al., 2015; Mander et al., 2017).

\section{CORRESPONDENCE}

AJ Rebelo

EMAIL

ARebelo@sun.ac.za

\section{DATES}

Received: 1 August 2018

Accepted: 17 August 2020

\section{KEYWORDS}

wetland evapotranspiration substomatal chambers crop factor

SEBAL Model

porometry

\section{COPYRIGHT}

(C) The Author(s)

Published under a Creative Commons Attribution 4.0 International Licence (CC BY 4.0) 
It is widely accepted in the literature that protecting Palmiet wetlands is beneficial in terms of habitat provision, sediment stabilisation and accretion, which creates storage capacity for water and increases the ability of the floodplain to absorb floodwaters and retain water to sustain dry-season flows (Job, 2014; Rebelo, 2017). However, it is also critical to understand the water-use of such an important and dominant wetland species to determine whether its presence constitutes a gain, in terms of water preserved in the ecosystem (where Palmiet wetland evapotranspiration is less than or equal to an equivalent area of open water) or a loss (where it exceeds evaporation) (Mohamed et al. 2012; Doody et al., 2014). Catchments containing Palmiet wetlands are currently being extensively modelled using ACRU and MIKE-SHE hydrological models to examine the benefits of rehabilitation or to compare climate or habitat scenarios (Rebelo et al., 2015; Mander et al., 2017). Evapotranspiration of various vegetation types is typically modelled by applying different sets of crop factors to a grass reference evapotranspiration (Schulze, 1995; Savage et al., 2010; Jovanovic and Israel, 2012). Therefore, it is essential to have a realistic crop factor to accurately represent the water-use of Palmiet in these hydrological models.

We aimed to develop an understanding of Palmiet water-use by quantifying: (i) factors influencing Palmiet water-use; (ii) seasonal variations in Palmiet plant and wetland water-use, (iii) an annual estimate of Palmiet wetland evapotranspiration, and (iv) a set of crop factors $\left(K_{\mathrm{c}}\right)$ for Palmiet wetlands. Many methods have been developed to measure the water-use of plants at the leaf, plant, and ecosystem scale. At the leaf scale, stomatal conductance can be used as an indicator for water-use, as it measures the passage of carbon dioxide or water vapour exiting stomata (a measure of the degree of stomatal opening). At the stand or landscape scale, the Surface Energy Balance Algorithm for Land (SEBAL) model uses the energy balance to model evapotranspiration using inputs from remote sensing and climatic variables (Bastiaanssen et al., 1998; Meijninger and Jarmain, 2014). We used morphology measurements and porometry to understand factors influencing water-use, and a combination of porometry and energy-balance modelling at the landscape scale using remote-sensing inputs to investigate seasonal variations. The results were also used to estimate annual evapotranspiration, the pan coefficient and a crop factor for Palmiet wetlands.

\section{METHODS}

\section{Study sites}

Two Palmiet wetlands were selected as study sites: one in the Jonkershoek valley $\left(33^{\circ} 58^{\prime} 38^{\prime \prime} \mathrm{S}, 18^{\circ} 56^{\prime} 48^{\prime \prime} \mathrm{E}\right)$ and another near the Theewaterskloof Dam ( $33^{\circ} 57^{\prime} 50^{\prime \prime}$ S, $\left.19^{\circ} 10^{\prime} 00^{\prime \prime} \mathrm{E}\right)$ in the Western Cape (Fig. 1). The Jonkershoek valley has a mean annual precipitation of $\pm 1427 \mathrm{~mm}$ (Scott, 1999), whereas that of the Theewaterskloof wetland is around $\pm 1241 \mathrm{~mm}$ (Kotze, 2015). Porometry measurements of stomatal conductance were collected in the field from the Jonkershoek wetland, whereas the SEBAL model was used to estimate the surface energy balance and evapotranspiration from the Theewaterskloof wetland. The reason that two different wetlands were used in this study is that the SEBAL data were available from other studies done by Meijninger and Jarmain (2014) and Klaasse et al. (2008).

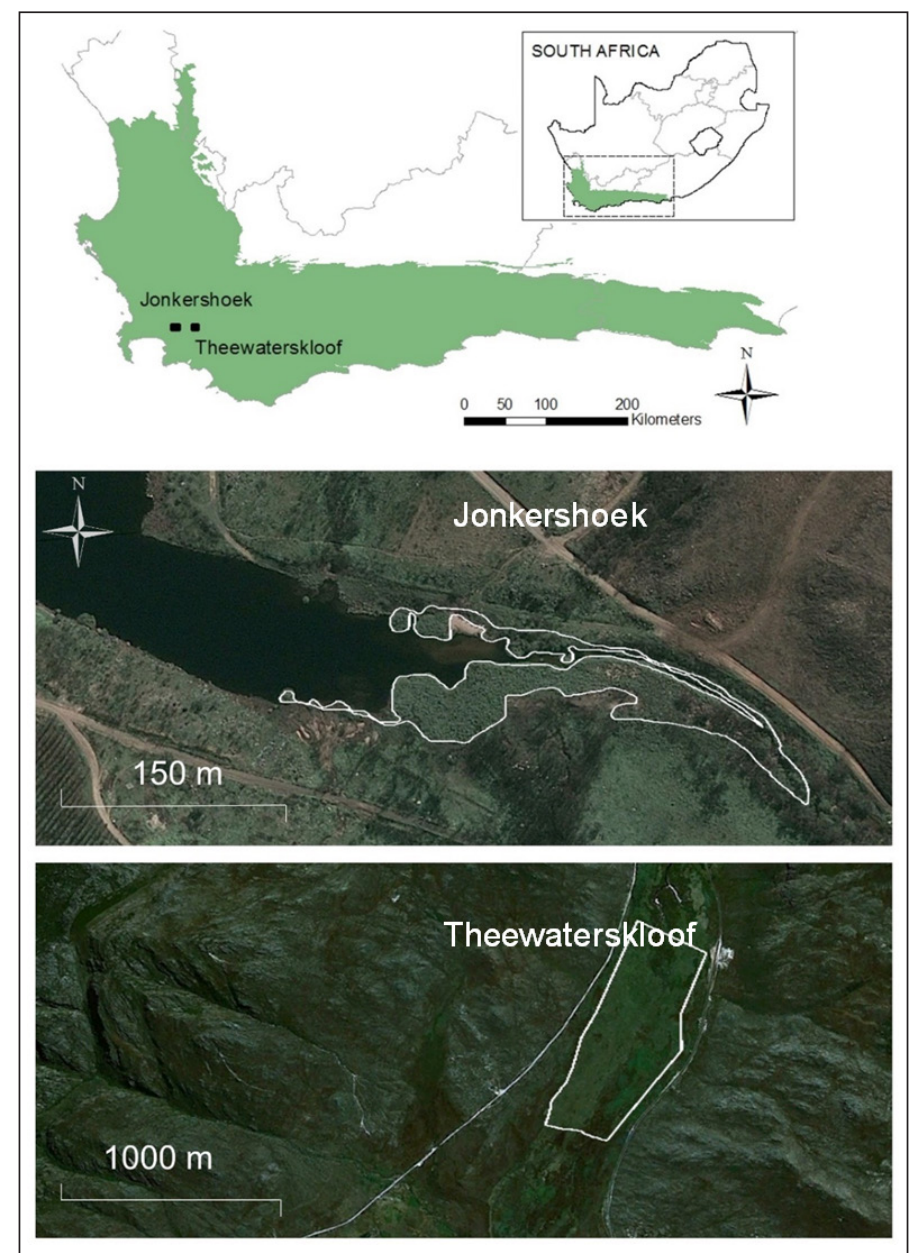

Figure 1. The location of the Jonkershoek and Theewaterskloof Palmiet wetlands within the Cape Floristic Region of South Africa (green area on the map inset). The gray lines in the maps indicate the provinces on the map inset. The approximate wetland area is indicated by white polygons in the satellite imagery which was dated 9/11/2009, obtained from Google Earth 


\section{Plant-scale field measurements}

In the Jonkershoek Palmiet wetland, a stand of Palmiet (Prionium serratum) was selected for sampling. The number of plants in ten $1 \mathrm{~m}^{2}$ plots were counted, as well as the number of dead and living leaves per plant for 10 plants. The length of 50 Palmiet leaves was also measured. Leaf area index was measured using an ACCUPAR LP-80 Leaf Area Index Meter (Decagon Devices, 2010) on a cloudy day in autumn. Leaf area index is a measure of the area of leaves of a plant per unit of ground area, and is used as an index for biomass, canopy cover, transpiration and productivity (Jarvis and Leverenz, 1983; Decagon Devices, 2010). Additionally, a leaf was collected from this Palmiet stand, and an epidermal peel made of both adaxial and abaxial surfaces using clear enamel. This epidermal peel was examined under a light microscope at $4 \mathrm{x}$, 10x and 40x magnifications and the number of stomata compared between both surfaces. Cross-sections through the Palmiet leaf were made and these were examined and photographed at various magnifications under a light microscope.

Stomatal conductance $\left(\mathrm{mmol} \cdot \mathrm{m}^{-2} \cdot \mathrm{s}^{-1}\right)$ and leaf temperature $\left({ }^{\circ} \mathrm{C}\right)$ of Palmiet were measured on 6 plants at Jonkershoek wetland over 2 to 3 days in 3 different seasons: late spring 2010 ( 3 and 10 November 2010), late summer 2011 (26-27 February and 2 March 2011) and early winter 2011 (10 and 11 June 2011). Measurements were taken hourly, starting from 07:00 and ending by 19:00 (depending on the daylight hours for each season) using a SC1 Leaf Porometer (Decagon Devices, 2012), ensuring light levels were adequate and leaves were dry (i.e. no rainfall). Three Palmiet plants were selected along the water's edge, and three were selected inland. Two leaves were sampled per plant and both the adaxial and abaxial surface of each leaf was sampled, yielding 4 measurements per plant per hour. Light conditions of each reading were recorded: whether the leaf was positioned in the shade or sun, whether conditions were cloudy, or whether the sun had set. A pilot study revealed that leaf age and aspect did not significantly affect stomatal conductance, therefore these factors were excluded in the final sampling design (Rebelo, 2012).

The range of stomatal conductance of Palmiet used for comparison with other species in other studies was calculated by taking the mean of the daily minimum and maximum values obtained during fieldwork. For comparison with other studies, all literature values of stomatal conductance were converted to $\mathrm{mmol} \cdot \mathrm{m}^{-2} \cdot \mathrm{s}^{-1}$. Von Willert et al. (1989) reported stomatal conductance values in $\mathrm{mmol} \cdot \mathrm{m}^{-2} \cdot \mathrm{s}^{-1}$ and therefore results didn't need conversion, whereas Miller et al. (1984) reported values as $\mathrm{mm} \cdot \mathrm{s}^{-1}$ and therefore all results had to be converted into molar values. This was done using the molar density of air $\left(\mathrm{mol} \cdot \mathrm{m}^{-3}\right)$, which was calculated taking into account local atmospheric pressure and temperature using the following formula:

$$
\rho=44.6 \times\left(P_{\text {atm }} / 101.3\right) \times(273.15 /(273.15+T))
$$

where $\rho$ is the molar density of air $\left(\mathrm{mol} \cdot \mathrm{m}^{-3}\right), P_{\text {atm }}$ is atmospheric pressure $(\mathrm{kPa})$, and $T$ is local temperature $\left({ }^{\circ} \mathrm{C}\right)$. Local atmospheric pressure $\left(P_{\text {atm }}\right)$ was calculated using the following formula:

$$
P_{\text {atm }}=101.3 \times \operatorname{EXP}(-\alpha / 8200)
$$

where $\alpha$ is the local elevation (in $\mathrm{m}$ above mean sea level; $\mathrm{m}$ amsl). Temperatures and elevations used for each location were: Algeria $\left(18^{\circ} \mathrm{C}, 500 \mathrm{~m}\right.$ amsl), Jonkershoek $\left(16^{\circ} \mathrm{C}, 282 \mathrm{~m}\right.$ amsl), Jakkalsrivier $\left(15^{\circ} \mathrm{C}, 960 \mathrm{~m}\right.$ amsl $)$ and Pella $\left(16^{\circ} \mathrm{C}, 300 \mathrm{~m} \mathrm{amsl}\right)$, yielding molar densities of air of $39.4,40.7,37.6$, and $40.6 \mathrm{~mol} \cdot \mathrm{m}^{-3}$, respectively. Meteorological data for the plant-scale field measurements were obtained from the closest local South African Weather Service station at Swartboskloof.

\section{Wetland-scale field measurements}

Scaling stomatal conductance up to plant or stand-level has high error associated with it (Whitehead, 1997), so it was not undertaken here. Rather, stomatal conductance results were compared with literature for other Fynbos species. To estimate annual evapotranspiration of Palmiet, we used a dataset where evapotranspiration and the energy balance from a Palmiet wetland had been modelled. This dataset was made available to support this analysis (Jarmain, 2009). We also calculated a set of crop factors $\left(K_{c}\right)$ for use in hydrological modelling studies.

\section{Wetland scale energy balance modelling using remote sensing inputs}

SEBAL was used to model the energy balance and evapotranspiration around the region of the Theewaterskloof wetland as part of research by Meijninger and Jarmain (2014) and Klaasse et al. (2008). Remote-sensing data from two sensors of different spatial and spectral resolutions were used as input into the SEBAL Model. Firstly, the Moderate Resolution Imaging Spectroradiometer (MODIS; Meijninger and Jarmain, 2014) and, secondly, Landsat7-ETM+ (Klaasse et al., 2008). The data from these projects were made available for this research. The data for the Theewaterskloof Palmiet wetland were extracted from the full dataset using a polygon of the extent of the wetland (following the method described in Singels et al., 2018). The resolution at which SEBAL outputs were provided was $250 \mathrm{~m}-1 \mathrm{~km}$ for MODIS outputs and 30-60 $\mathrm{m}$ for Landsat7. For this analysis, the mean monthly evapotranspiration for the entire Palmiet wetland was calculated for each scene, resulting in a mean and standard deviation value ( $\mathrm{mm} / \mathrm{month}$ ) for each scene (Tables A1, A2). Meteorological data used in the model were obtained from local weather stations at Franschhoek and Villiersdorp, managed by the South African Weather Service. Monthly rainfall data are presented in Fig. A1 (Appendix).

Details on the SEBAL modelling using the MODIS imagery are described in Meijninger and Jarmain (2014). One MODIS scene per month was selected from 3 hydrological years (July to June inclusive) (2000-2001, 2002-2003, 2006-2007). Scenes obscured by cloud cover were excluded from analysis, resulting in 6 months of missing data over the 36 months sampled (Table A1; Appendix). Crop resistance $\left(\mathrm{s} \cdot \mathrm{m}^{-1}\right)$ was also calculated and extracted from the SEBAL outputs, and therefore stomatal conductance, the inverse, could also be estimated $\left(\mathrm{m} \cdot \mathrm{s}^{-1}\right)$. Details on the SEBAL modelling using Landsat7 imagery are described in Klaasse et al. (2008). One Landsat7 scene per month (or 2 for 2 months combined) were selected over the growing season (September to April) of 3 hydrological years (2004-2005, 2005-2006, 2006-2007) (Table A2; Appendix). Evapotranspiration rates were calculated from instantaneous and daily energy balance results from the SEBAL model, and extrapolated to a monthly sum using meteorological data (Klaasse et al., 2008).

\section{Crop factor calculations}

Crop factors are used as a multiplying factor to estimate actual evapotranspiration rates for various types of vegetation cover, applied to a grass reference evapotranspiration rate (Allen et al., 1998; Savage et al., 2010). Therefore, the crop factor distinguishes different vegetation types from a grass reference crop with no water or nutrient stress (Allen et al., 1998). Grass reference evapotranspiration rates are usually calculated at an automatic weather station using the Penman-Monteith approach based on various atmospheric measurements (Savage et al., 2010). Crop factors are calculated by the quotient of evapotranspiration and reference evapotranspiration. A crop factor for Palmiet wetlands was calculated in this way, using the estimated evapotranspiration 
from the SEBAL outputs (using MODIS- and Landsat7 data) and reference evapotranspiration which was obtained from the local weather stations described above. The caveat of this approach is that it is not known whether Palmiet in the Theewaterskloof wetland was water-stressed in any of the monthly scenes over the three hydrological years of measurement. However, Palmiet wetlands are highly connected to fluvial systems, and it is thought that they are fed to some extent by groundwater; therefore they are less likely to experience water-stress than terrestrial vegetationtypes (Job, 2014; Rebelo, 2017). Therefore, this crop factor for Palmiet wetlands is useful as a first estimate, but further research is needed.

\section{Data analysis}

All field-measured stomatal conductance data were screened and found to be normally distributed. A mixed model repeated measures analysis of variance (ANOVA) was used to determine the significance of the difference between stomatal conductance measurements for three variables (level of inundation of the soil, abaxial/adaxial leaf surface, whether the leaf was positioned in the shade or the sun) at different times of day and in different seasons (Tables A3-A5; Appendix). Linear mixed models in R were used to confirm these results (lme4 package; Bates et al., 2015, Table A6; Appendix). Pearson correlations were used to investigate the relationship between measured stomatal conductance and various weather station measured climatic variables (wind speed, vapour pressure, saturated vapour pressure, temperature, vapour pressure deficit, radiation, potential evaporation, and relative humidity) (Fig. A2; Appendix). A 'Classification And Regression Tree' (CART) Analysis (Breiman et al., 1984) was used to determine the relative importance of variables significantly affecting stomatal conductance (Fig. A3; Appendix).

Monthly Landsat7 SEBAL evapotranspiration values were not available for the three winter months. Therefore, to estimate annual evapotranspiration, the monthly dataset was interpolated using a linear model based on the relationship between monthly Landsat7 and MODIS SEBAL evapotranspiration (Pearson correlation: $r=0.87$ ) (Fig. A4; Appendix). Comparisons between field measurements and modelled stomatal conductance and crop factors were also made using Pearson correlations.

\section{RESULTS}

In an average stand of Palmiet (Prionium serratum), the mean ( \pm standard deviation) number of plants per $\mathrm{m}^{2}(n=10)$ is $7.0 \pm$ 1.76. The mean $(n=10)$ number of living leaves per plant is 48.3 \pm 13.56 , and dead leaves is $8.3 \pm 5.03$. The mean $(n=50)$ length of leaves is $89.7 \pm 11.75 \mathrm{~cm}$. The leaf area index of Palmiet is $11.2 \pm 1.10$ $(n=25)$. The number of stomata does not differ between adaxial and abaxial leaf surfaces of Palmiet leaves. From an epidermal peel of both surfaces, stomata do not appear to be sunken (Fig. 2a), as stomatal guard cells are located at the leaf surface. Yet, crosssections through a Palmiet leaf reveal large substomatal chambers behind the guard cells (Fig. 2b-e).

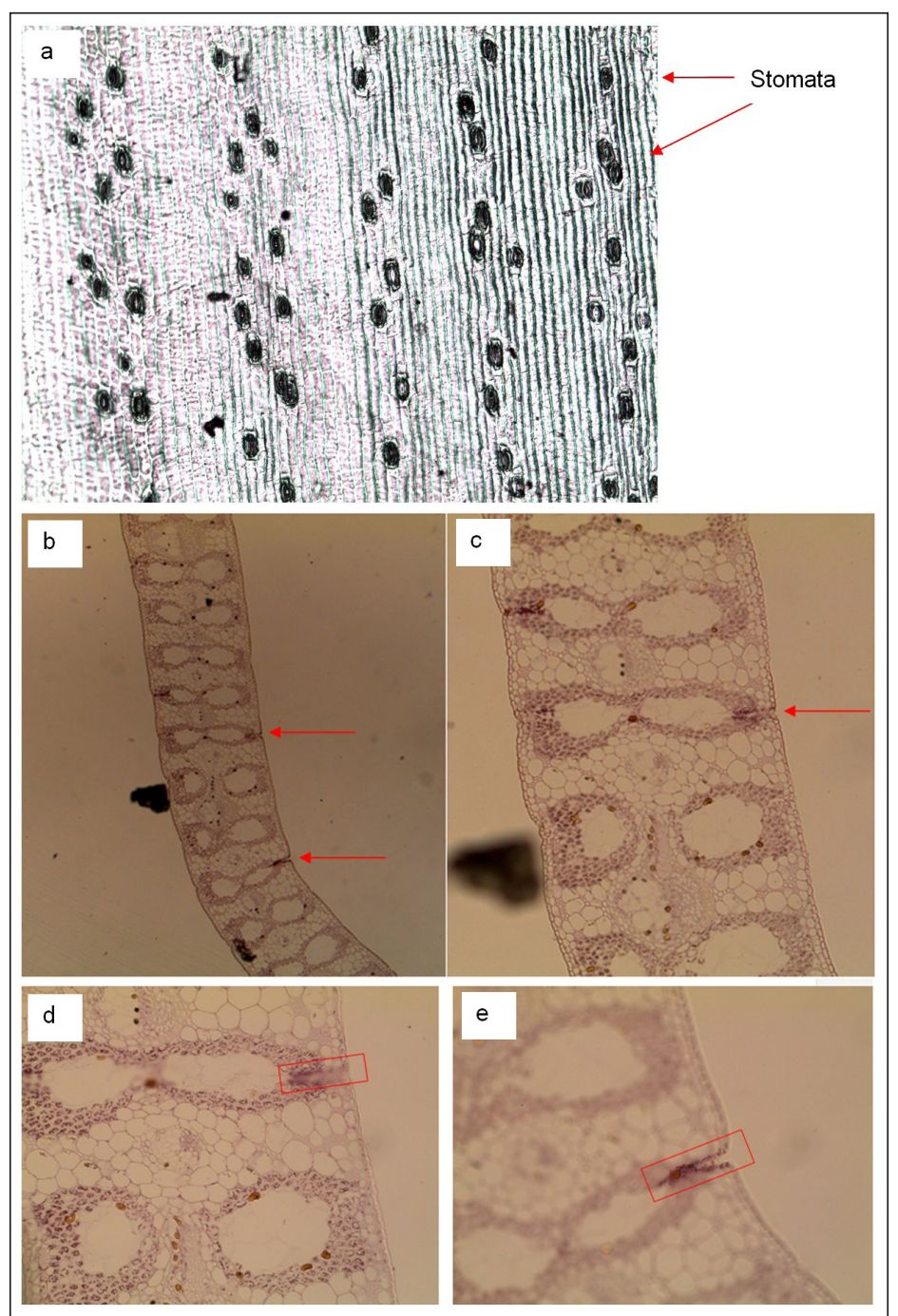

Figure 2. (a) Epidermal peel of the adaxial surface of a leaf of Palmiet (Prionium serratum) (10x), and cross sections through leaves at (b) $4 x$, (c) $10 x$, and $(d, e) 20 x$. Red arrows and squares indicate the position of stomatal apertures 


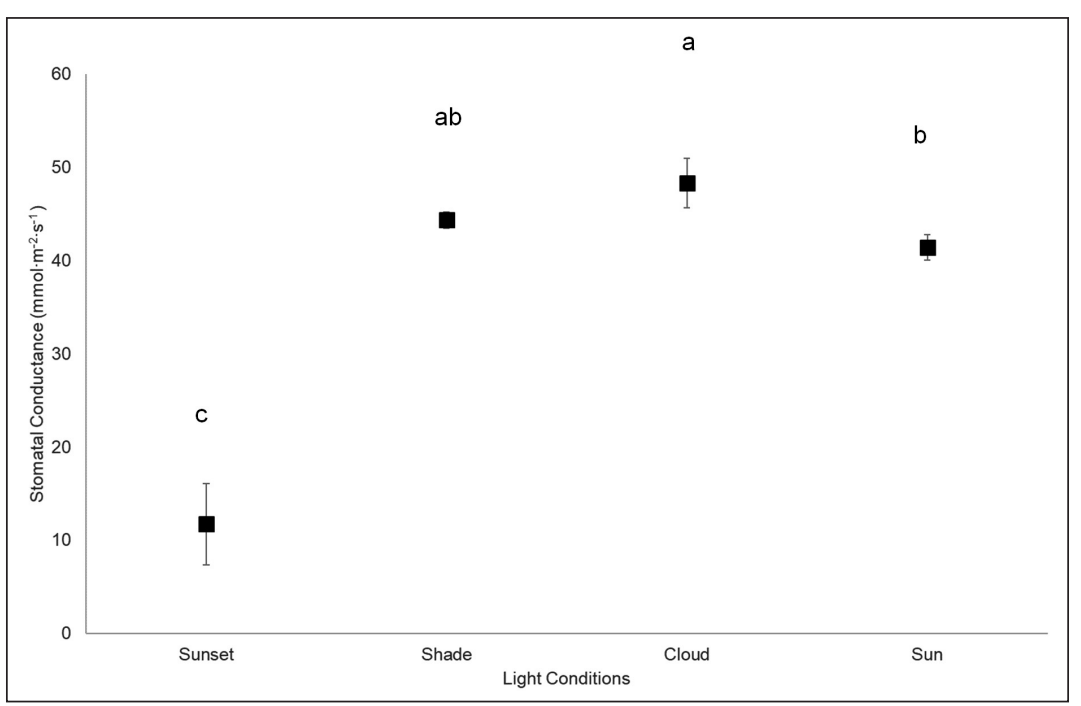

Figure 3. The effect of light conditions on stomatal conductance of Palmiet plants (Prionium serratum) in Jonkershoek, Western Cape. Blocks represent means and bars the $95 \%$ confidence intervals. Points with the same letters denote no significant difference

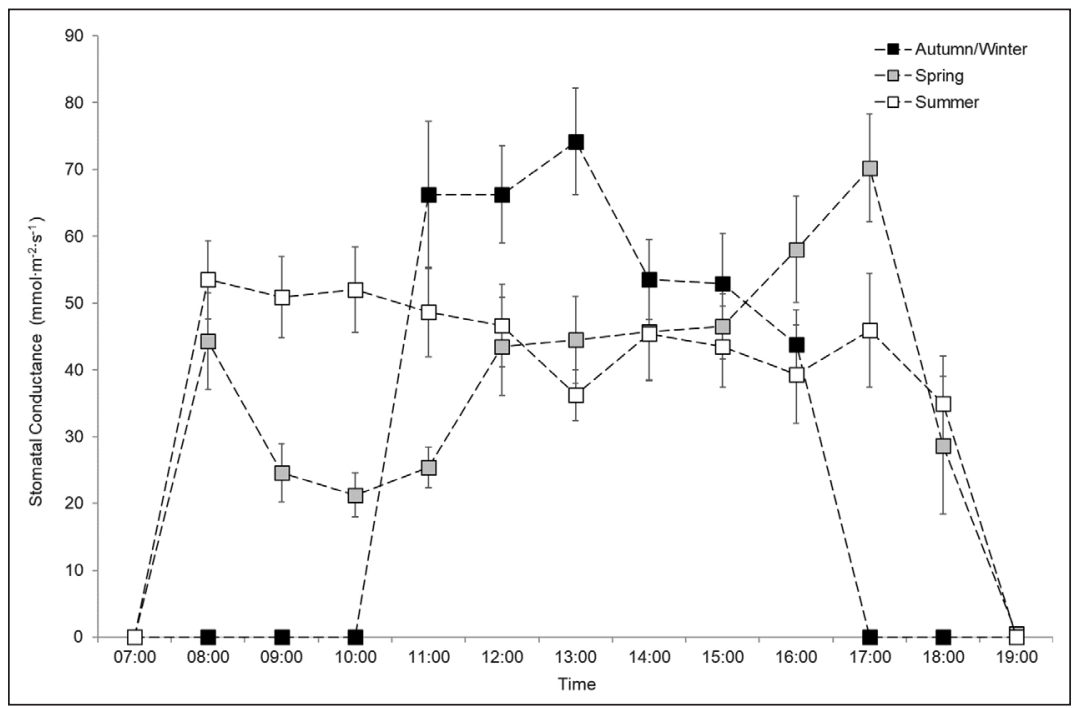

Figure 4. The effect of season and time on mean ( $\pm 95 \%$ confidence interval) stomatal conductance of Palmiet (Prionium serratum) in Jonkershoek, Western Cape

Stomatal conductance of Palmiet ranged from 11-152 mmol. $\mathrm{m}^{-2} \cdot \mathrm{s}^{-1}$ daily and did not differ significantly with inundation, or between the abaxial and adaxial surfaces (Table A6; Appendix). Three variables were found to be important in influencing stomatal conductance in both a CART analysis (\%) and using linear mixed models: light condition the leaves were exposed to (100\%, Fig. 3 and Fig. A3; Appendix), the season (87\%) and the time of day (82\%) (Fig. 4, Table A6; Appendix). Palmiet stomatal conductance was significantly higher in cloudy compared to sunny conditions (Fig. 3, Table A4; Appendix). Before the sun rose in the morning stomatal conductance was undetectable, and after the sun set in the evening, stomatal conductance dropped significantly until it again became undetectable (Fig. 4). Wind speed, saturated vapour pressure, temperature, vapour pressure deficit, radiation, potential evaporation and relative humidity had no significant effect on the stomatal conductance of Palmiet (Fig. A2; Appendix). Vapour pressure had a significant positive effect on stomatal conductance $(p<0.05, t=1.94)$.

Diurnal patterns of stomatal conductance differed significantly $(p<0.05)$ among seasons (Fig. 4, Table A5, Table A6; Appendix). In spring, stomatal conductance was low in the early morning and increased toward sunset (mean: $34.9 \mathrm{mmol} \cdot \mathrm{m}^{-2} \cdot \mathrm{s}^{-1}$ ). In summer, stomatal conductance was maintained at a mostly constant level throughout the day (mean: $38.2 \mathrm{mmol} \cdot \mathrm{m}^{-2} \cdot \mathrm{s}^{-1}$ ) whilst in winter it was relatively high in the morning and declined towards the end of the day (mean: $27.4 \mathrm{mmol} \cdot \mathrm{m}^{-2} \cdot \mathrm{s}^{-1}$.

SEBAL model results using Landsat-7 as input gave the highest estimate for mean annual evapotranspiration of Palmiet, based on 7 months of data (spring, summer, autumn) over 3 hydrological years, and MODIS-SEBAL model results gave the lowest, based on 12 months of data over 3 hydrological years (Table 1). However, these estimates were reasonably well correlated ( $r=0.87$, Fig. A4; Appendix). The mean of the annual estimates calculated is $1220 \mathrm{~mm} \cdot \mathrm{a}^{-1}$. Evapotranspiration of Palmiet wetlands was higher in summer than winter (seasonal trends in Fig. A5; Appendix). The MODIS SEBAL model estimates for monthly stomatal conductance of the Theewaterskloof Palmiet wetland were somewhat lower than the stomatal conductance measured on 6 Palmiet plants at Jonkershoek, and they were poorly correlated ( $r=0.34$, Fig. A6). Stomatal conductance tended to be higher in winter (seasonal trends in Fig. A5; Appendix). The mean MODIS crop factor was slightly lower than that of Landsat7, and the monthly crop factors for the two were poorly correlated $(r=0.47)$. A-Pan evaporation was $2809 \mathrm{~mm} \cdot \mathrm{a}^{-1}$ on average from 1990-2005 according to the Villiersdorp weather station (Table A7; Appendix). Therefore, the pan coefficient (the ratio of mean evapotranspiration to mean pan evaporation) for Palmiet wetlands ranges from 0.37-0.50 (mean: 0.46) based on evapotranspiration in Table 1. 
Table 1. A comparison of water-use values for Palmiet (Prionium serratum), in terms of evapotranspiration (Et) and stomatal conductance (cond.) across all scales, sites and methods used in this study. The $\left(^{*}\right)$ symbol indicates the interpolated Landsat7 values (calculated using a linear model based on the relationship between monthly Landsat7- and MODIS-SEBAL evapotranspiration $(r=0.87))$. The crop factors $\left(\left(K_{c}\right)\right.$ are calculated from the quotient of evapotranspiration and reference evapotranspiration. Note, the $K_{c}$ values cannot be guaranteed to be stress-free values (see discussion in methods) (Allen et al. 1998)

\begin{tabular}{|c|c|c|c|c|c|c|}
\hline \multirow[t]{2}{*}{ Month } & $\begin{array}{l}\text { Remote } \\
\text { sensing }\end{array}$ & $\begin{array}{l}\text { Remote } \\
\text { Sensing }\end{array}$ & Porometry & $\begin{array}{l}\text { Remote } \\
\text { sensing }\end{array}$ & $\begin{array}{l}\text { Remote } \\
\text { sensing }\end{array}$ & $\begin{array}{l}\text { Remote } \\
\text { Sensing }\end{array}$ \\
\hline & $\begin{array}{c}\text { SEBAL Et (based on } \\
\text { Landsat7 inputs) } \\
(\mathrm{mm})\end{array}$ & $\begin{array}{l}\text { SEBAL Et (based } \\
\text { on MODIS inputs) } \\
(\mathrm{mm})\end{array}$ & $\begin{array}{l}\text { Stomatal cond. } \\
\left(\mathrm{mmol} \cdot \mathrm{m}^{-2} \cdot \mathrm{s}^{-1}\right)\end{array}$ & $\begin{array}{l}\text { Stomatal cond. (based } \\
\text { on MODIS inputs) } \\
\left(\mathrm{mmol} \cdot \mathrm{m}^{-2} \cdot \mathrm{s}^{-1}\right)\end{array}$ & $\begin{array}{c}\text { Landsat7 } \\
K_{\mathrm{c}}\end{array}$ & $\begin{array}{c}\text { MODIS } \\
K_{\mathrm{c}}\end{array}$ \\
\hline January & 188.61 & 153.60 & & 17.41 & 1.38 & 1.00 \\
\hline February & 163.91 & 129.47 & 40.89 & 17.12 & 1.31 & 1.09 \\
\hline March & 102.90 & 87.67 & 46.08 & 14.04 & 1.03 & 1.04 \\
\hline April & $108.01^{*}$ & 81.27 & & 32.85 & & 1.20 \\
\hline May & $51.21^{*}$ & 43.39 & & 21.30 & & 1.10 \\
\hline June & $43.14^{*}$ & 38.00 & 59.86 & 25.99 & & 1.15 \\
\hline July & $30.53^{*}$ & 29.59 & & 14.02 & & 0.94 \\
\hline August & $55.53^{*}$ & 46.27 & & 32.18 & & 1.01 \\
\hline September & 132.75 & 73.51 & & 29.16 & 1.07 & 1.12 \\
\hline October & 133.95 & 102.23 & 48.50 & 23.77 & 1.00 & 1.07 \\
\hline November & 166.90 & 110.29 & 36.85 & 28.20 & 1.16 & 1.00 \\
\hline December & 220.21 & 147.65 & 31.86 & 33.69 & 1.48 & 1.01 \\
\hline Annual estimate (Mean) & 1397.64 & 1042.94 & 44.01 & 24.15 & 1.20 & 1.06 \\
\hline
\end{tabular}

Table 2. Ranges of leaf stomatal conductance $\left(\mathrm{mmol} \cdot \mathrm{m}^{-2} \cdot \mathrm{s}^{-1}\right)$ for different growth forms of Fynbos from the Cape Floristic Region, South Africa. Table adapted from Von Willert et al. (1989) and Miller et al. (1984)

\begin{tabular}{|c|c|c|c|c|c|c|c|}
\hline \multirow[t]{2}{*}{ Source } & \multirow[t]{2}{*}{ Location } & \multicolumn{6}{|c|}{ Leaf stomatal conductance $\left(\mathrm{mmol} \cdot \mathrm{m}^{-2} \cdot \mathrm{s}^{-1}\right)$} \\
\hline & & Tall shrub & Mid shrub & Restioid & Geophyte & Graminoid & Palmiet \\
\hline \multirow[t]{7}{*}{ Miller et al., 1984} & Cederberg (Algeria: Waboomveld) & $75-217$ & $31-665$ & $134-339$ & $110-146$ & - & - \\
\hline & Cederberg (Algeria: 23 years) & $43-264$ & $71-598$ & $283-445$ & - & - & - \\
\hline & Jonkershoek (Waboomveld) & $90-452$ & $90-452$ & - & - & - & - \\
\hline & Jonkershoek (Swartboskloof) & $45-904$ & $37-1100$ & - & - & $252-358$ & - \\
\hline & Jonkershoek (Langrivier) & $77-528$ & $191-213$ & $265-427$ & 195 & - & - \\
\hline & Jakkalsrivier & $60-143$ & 425 & 350 & - & 105 & - \\
\hline & Pella & $126-455$ & $57-646$ & $219-585$ & - & - & - \\
\hline Von Willert et al., 1989 & Cederberg & $68-157$ & $61-125$ & 89-139 & 226 & 91 & - \\
\hline This study & Jonkershoek & - & - & - & - & - & $11-152$ \\
\hline
\end{tabular}

\section{DISCUSSION}

The leaf area index of Palmiet measured in this study was very high relative to other vegetation types, commensurate with its high biomass and therefore possibly indicative of high transpiration. In a global synthesis of leaf area index measurements, deserts had the lowest values, with a mean \pm standard deviation of $1.3 \pm 0.9$, tree plantations had the highest values $(8.7 \pm 4.3)$ followed by temperate evergreen forests (ranging from a mean of 5.1-6.7) and then wetlands $(6.3 \pm 2.3)$ (Asner et al., 2003). The leaf area index for Fynbos has been estimated as 2-3 (Miller et al., 1984).

The possibly high transpiration hinted at by Palmiet's leaf area index value is at odds with its atypical leaf morphology. Stomatal guard cells open into large cavities, or 'substomatal chambers' within the leaf, identical on both leaf surfaces, suggesting an adaptation to enhance carbon dioxide influx or minimize water vapour efflux or both (Pickard, 1982). One possible explanation for these xeromorphic adaptations could be the seasonal nature, or interannual variation, of water saturation in wetlands throughout the Cape Floristic Region. A second theory could be that oligotrophic soils (and groundwater) explain the extreme sclerophylly of the species (Specht, 1988; Esler et al., 2018). An excess of moisture, but shortage of phosphorus, could lead to the accumulation of carbon, which is consequently allocated to structural phenomena, such as thicker leaves (Medina et al., 1990).

Palmiet appears to have a lower stomatal conductance than most other terrestrial Fynbos plants (Table 2). This is counter-intuitive given that Palmiet is a wetland plant and is thought to have essentially unlimited access to water in the root zone. In terms of rates of stomatal conductance, Palmiet compares most closely with that of terrestrial mid-sized shrubs and Restioids in the Cederberg; 11-152 compared to 61-125 and 89-139 $\mathrm{mmol} \cdot \mathrm{m}^{-2} \cdot \mathrm{s}^{-1}$, respectively (Von Willert et al., 1989). Annual evapotranspiration of riparian Fynbos (a Restioid wetland) in Jonkershoek was estimated at $1332 \mathrm{~mm} \cdot \mathrm{a}^{-1}$ using the Bowen ratio energy balance technique (mean annual precipitation of $1324 \mathrm{~mm}$ ) (Dye et al., 2001). Based on the evidence that Palmiet has lower stomatal conductance than Restioid wetlands, it is likely that the annual evapotranspiration of the Palmiet wetland in Jonkershoek is lower than $1332 \mathrm{~mm} \cdot \mathrm{a}^{-1}$. This corresponds well to the mean of the Landsat7 and MODIS SEBAL annual evapotranspiration estimates of $1220 \mathrm{~mm} \cdot \mathrm{a}^{-1}$.

A recent study on the evapotranspiration of Palmiet wetlands found that the growing season evapotranspiration (October to April) ranged from $138 \mathrm{~mm} \cdot \mathrm{a}^{-1}$ to $1204 \mathrm{~mm} \cdot \mathrm{a}^{-1}$, depending on the 
wetland size, climatic region and the model used (Ramatsabana et al., 2019). The growing season evapotranspiration (September to March) estimated by the SEBAL model using Landsat7 and MODIS in this study was $1109.23 \mathrm{~mm} \cdot \mathrm{a}^{-1}$ and $885.69 \mathrm{~mm} \cdot \mathrm{a}^{-1}$, respectively. Factors contributing to the difference in monthly evapotranspiration between the Landsat7 and MODIS SEBAL models include: (i) that satellite data were from different dates (years) with different climatological conditions, (ii) the differences in spatial and temporal resolutions of the data and hence the landcover considered (e.g. more landcover adjacent to wetland included for coarser imagery), and (iii) gaps in the measurements and errors associated with the data infilling approach (e.g., simple linear mixed model for Landsat7). This range in Palmiet mean annual evapotranspiration for the different methods therefore gives an idea of associated error or possibly even of variation in annual evapotranspiration. Further research is needed to improve the measurements of water-use of this, and other, key wetland species in South Africa.

The Palmiet mean annual evapotranspiration (mean of the Landsat7 and MODIS SEBAL outputs) is lower than reference evapotranspiration for the catchment $\left(1302 \mathrm{~mm} \cdot \mathrm{a}^{-1}\right.$ on average from 2004-2007 according to the Villiersdorp weather station, Table A8; Appendix), and far lower than A-Pan evaporation (2 $809 \mathrm{~mm} \cdot \mathrm{a}^{-1}$ on average from 1990-2005 according to the Villiersdorp weather station, Table A7; Appendix). A-Pan evaporation is a theoretical indication of open water evaporation, and reference evapotranspiration indicative of a short, wellwatered grass surface with no water or nutrient stress (Allen et al., 1998). Therefore, water salvage from clearing Palmiet from a wetland is highly unlikely and retaining the wetlands is likely to constitute water savings. The pan coefficient for Palmiet wetlands shows the same trend as global studies (i.e. $<1$, suggesting that wetlands reduce evaporation efficiency compared to open water), but was markedly lower than the global average of $0.87 \pm 0.26$ for wetlands (Mohamed et al., 2012).

In south-eastern Australia this method for estimating water savings has been applied to the removal of in-stream invasive alien Salix species (Doody et al., 2014). Differences in the modelled (Penman-Monteith) evapotranspiration for Salix species and open-water evaporation (A-Pan) showed that 450 to $763 \mathrm{~mm}$ water could be returned to the environment per year (Doody et al., 2014). Given that Palmiet is a wetland species with moderate water-use, it must be able to exert some controls on water loss (Ramatsabana et al., 2019). For example, the mean annual evapotranspiration for an invasive alien tree (Acacia mearnsii) infestation in a riparian zone in the Western Cape is far higher. It is thought that annual evapotranspiration may exceed $1500 \mathrm{~mm} \cdot \mathrm{a}^{-1}$ where there are no soil water deficits throughout the year (Dye and Jarmain, 2004).

Stomatal conductance measurements recorded higher maxima in autumn/winter than in summer and spring. However, on average, stomatal conductance was still higher in summer and spring than in winter. It may be that Palmiet responds to warmer conditions and increased radiance by reducing the size of its stomatal aperture, decreasing stomatal conductance. Again, this physiological adaptation is counter-intuitive for a wetland plant which has no shortage of water, but we hypothesize that this may be its means of persistence during interannual periods of drought (e.g. such as the 2015-2017 southwestern Cape drought). However, a second theory is that Palmiet has 'cool climate growth' adaptations, like most Fynbos plants (Esler et al., 2018).

Despite having higher stomatal conductance maxima in winter, evapotranspiration of Palmiet wetlands was consistently higher during the warmer months than in winter, across all methods. Winter MODIS SEBAL modelled evapotranspiration of Palmiet wetlands was only $26 \%$ of summer modelled evapotranspiration. Spring MODIS SEBAL modelled evapotranspiration of Palmiet wetlands was $66 \%$ of the same for summer, whereas spring Landsat7 SEBAL modelled evapotranspiration was $76 \%$ of summer evapotranspiration. Another study on Palmiet wetland water-use noted similar significant seasonal variations, as well as regional variations linked to local climate (Ramatsabana et al., 2019).

The poor correlation between measured stomatal conductance and the MODIS SEBAL model stomatal conductance outputs supports the notion that it is difficult, if not impossible, to scale up from stomatal conductance to evapotranspiration, or vice versa, without complex models (Ding et al., 2014). However modelling evapotranspiration for these small wetlands using satellite imagery is not without challenges at the spatial resolutions at which that imagery is currently available. In another study on Palmiet wetlands, the relatively coarse spatial resolution of satellite imagery resulted in the interference of adjacent landcover in water-use signals of Palmiet wetlands (Ramatsabana et al., 2019). For this study, it should also be noted that local differences in climate between the Jonkershoek and Theewaterskloof valleys may also play a role in driving these slight differences in water-use by the plant Palmiet.

In conclusion, it seems that Palmiet has moderate water-use for a Fynbos riparian species (and certainly relative to invasive alien trees in riparian zones), which is an added benefit to retaining and preserving native vegetation in Palmiet wetlands. Palmiet appears to have morphological and physiological adaptations to limit water-use, despite growing exclusively in riparian areas. These adaptations may have ensured the competitiveness of Palmiet during extremely dry years, or may be linked to adaptations to oligotrophy, two possible theories explaining its dominance in valley-bottom wetlands.

\section{ACKNOWLEDGEMENTS}

The South African Weather Service is acknowledged for access to meteorological data. The authors wish to thank the following organizations for funding: ASSET Research, the Water Research Commission of South Africa, the Fynbos Forum Innovation Scholarship (Table Mountain Fund and WWF), the HB Thom Fund, Dudley D'Ewes Scholarship (Cape Tercentenary Foundation), Consolidoc (Stellenbosch University) and the Ernst and Ethel Eriksen Trust.

\section{REFERENCES}

ALLEN RG, PEREIRA LS, RAES D and SMITH M (1998) Crop evapotranspiration - Guidelines for computing crop water requirements. FAO Irrigation and Drainage Paper 56. Food and Agriculture Organization of the United Nations, Rome. ISBN 92-5-104219-5.

ASNER GP, SCURLOCK JMO and HICKE JA (2003) Global synthesis of leaf area index observations: implications for ecological and remote sensing studies. Glob. Ecol. Biogeogr. 12 191-205. https://doi. org/10.1046/j.1466-822X.2003.00026.x

BASTIAANSSEN WGM, MENENTI M, FEDDES RA and HOLTSLAG AAM (1998) A remote sensing surface energy balance algorithm for Land (SEBAL), Part 1: Formulation. J. Hydrol. 212-213 198-212. https://doi.org/10.1016/S0022-1694(98)00253-4

BATES D, MAECHLER M, BOLKER B and WALKER S (2015) Fitting linear mixed-effects models using lme4. J. Stat. Softw. 67 (1) 1-48. http://doi.org/10.18637/jss.v067.i01

BIRKHEAD AL, OLBRICH BW, JAMES CS and ROGERS KH (1997) Developing an integrated approach to predicting the water use of riparian vegetation. WRC Report No. 474/1/97. Water Research Commission, Pretoria.

BOUCHER C and WITHERS MJ (2004) Notes on the ecology of Prionium serratum (Palmiet), a Cape river specialist. Veld \& Flora. 90 (1) 26-28. 
BREIMAN L, FRIEDMAN JH, OLSHEN RA and STONE CJ (1984) Classification and Regression Trees. Wadsworth \& Brooks/Cole Advanced Books \& Software. Monterey, CA.

CLULOW AD, EVERSON CS and GUSH MB (2011) The long-term impact of Acacia mearnsii trees on evaporation, streamflow, and ground water resources. WRC Report No. TT 505/11. Water Research Commission, Pretoria.

CLULOW D, EVERSON CS, MENGISTU MG, JARMAIN C, JEWITT GPW, PRICE JS and GRUNDLING P-L (2012) Measurement and modelling of evaporation from a coastal wetland in Maputaland, South Africa. Hydrol. Earth Syst. Sci. 9 1741-1782. https://doi.org/ 10.5194/hess-16-3233-2012

DECAGON DEVICES (2010) Leaf Area Index Meter -ACCUPAR LP80: Operators Manual Version 10. Decagon Devices, Inc., 2365 NE Hopkins Court. www.decagon.com.

DECAGON DEVICES (2012) Leaf Porometer: Operators Manual Version 11. Decagon Devices, Inc., 2365 NE Hopkins Court. URL: www.decagon.com.

DING R, KANG S, DU T, HAO X and ZHANG Y (2014) Scaling up stomatal conductance from leaf to canopy using a dual-leaf mode for estimating crop evapotranspiration. PLoS ONE. 9 (4) e95584. https://doi.org/10.1371/journal.pone.0095584

DOODY TM, NAGLER PL, GLENN EP, MOORE GW, MORINO K, HULTINE KR and BENYON RG (2011) Potential for water salvage by removal of non-native woody vegetation from dryland river systems. Hydrol. Process. 25 4117-4131. https://doi.org/10.1002/hyp.8395

DOODY TM, BENYON RG, THEIVEYANATHAN S, KOUL V and STEWART L (2014) Development of pan coefficients for estimating evapotranspiration from riparian woody vegetation. Hydrol. Process. 28 2129-2149. https://doi.org/10.1002/hyp.9753

DYE PJ and JARMAIN C (2004) Water use by black wattle (Acacia mearnsii): implications for the link between removal of invading trees and catchment streamflow response. S. Afr. J. Sci. 100 40-44.

DYE PJ, JARMAIN C, LE MAITRE DC, EVERSON CS, GUSH MB and CLULOW A (2008) Modelling vegetation water use for general application in different categories of vegetation. WRC Report No. 1319/1/08. Water Research Commission, Pretoria.

DYE PJ, MOSES G, VILAKAZI P, NDLELA R and ROYAPPEN M (2001) Comparative water use of wattle thickets and indigenous plant communities at riparian sites in the Western Cape and KwaZulu-Natal. Water SA. 27 (4) 529-536. http://doi.org/10.4314/ wsa.v27i4.4967

DZIKITI S, JOVANOVIC NZ, BUGAN R, ISRAEL S and LE MAITRE DC (2014) Measurement and modelling of evapotranspiration in three Fynbos vegetation types. Water SA. 40 (2) 189-198. http://doi. org/10.4314/wsa.v40i2.1

ESLER KJ, JACOBSEN AL and PRATT RB (2018) Form and function of Mediterranean shrublands. In: Esler KJ, Jacobsen $\mathrm{AL}$ and Pratt RB (eds) The Biology of Mediterranean-Type Ecosystems. Oxford University Press, Oxford. https://doi.org/10.1093/oso/978 0198739135.003 .0006

EVERSON CS, BURGER C, OLBRICH BW and GUSH MB (2001) Verification of estimates of water use from riverine vegetation on the Sabie River in the Kruger National Park. WRC Report No. 877/1/01. Water Research Commission, Pretoria.

EVERSON CS, MOLEFE GL and EVERSON TM (1998) Monitoring and modelling components of the water balance in a grassland catchment in the summer rainfall area of South Africa. WRC Report No. 493/1/98. Water Research Commission, Pretoria.

EVERSON CS, GUSH M, MOODLEY M, JARMAIN C and DYE P (2007) Effective management of the riparian zone vegetation to significantly reduce the cost of catchment management and enable greater productivity of land resources. WRC Report No. 1284/1/07. Water Research Commission, Pretoria.

EVERSON C, CLULOW A and MENGITSU M (2009) Feasibility study on the determination of riparian evaporation on non-perennial systems. WRC Report No. TT 424/09. Water Research Commission, Pretoria.

HAIGH EA, GRUNDLING P-L and ILLGNER PM (2002) Report on the scoping study on the status of the Kromme River peatland complex and recommended mitigatory measures. Department of Water Affairs and Forestry Project X832633. Department of Water Affairs and Forestry, Pretoria.
JARMAIN C (2009) Personal communication. SEBAL outputs obtained and personal communication. Data obtained in 2010. Centre for Geographical Analysis, Stellenbosch University, Private Bag X1, Matieland, 7600, South Africa.

JARVIS PG and LEVERENZ JW (1983) Productivity of temperate, deciduous and evergreen forests. In: Lange OL (ed.) Physiological Plant Ecology. IV. Encyclopedia of Plant Physiology, Vol. 12D. Springer-Verlag, New York. 233-280. https://doi.org/10.1007/978-3642-68156-1_9

JOB N (2014) Geomorphic origin and dynamics of deep, peat-filled, valley bottom wetlands dominated by Palmiet (Prionium serratum) - a case study based on the Goukou Wetland, Western Cape. Masters thesis, Rhodes University.

JOVANOVIC N and ISRAEL S (2012) Critical Review of methods for the estimation of actual evapotranspiration in hydrological models. In: Irmak A (ed.) Evapotranspiration - Remote Sensing and Modeling. IntechOpen. https://doi.org/10.5772/21279

KLAASSE A, BASTIAANSSEN W, BOSCH J, JARMAIN C and DE WIT M (2008) Water use efficiency of table and wine grapes in Western Cape, South Africa. WaterWatch Final Report for the Department of Agriculture, Western Cape. WaterWatch, Wageningen. URL: http://www.waterwatch.nl/fileadmin/bestanden/Project/Africa/ grapes/0169_ZA_2008_WCapeGrapes_finalreport.pdf .

KOTZE DC (2015) A survey of organic soils in the upper Riviersonderend catchment. Report to the WWF, South Africa (unpublished).

LE MAITRE DC, FORSYTH GG, DZIKITI S and GUSH MB (2016) Estimates of the impacts of invasive alien plants on water flows in South Africa. Water SA. 42 (4) 659-672. https://doi.org/10.4314/wsa. v42i4.17

MANDER M, JEWITT G, DINI J, GLENDAY J, BLIGNAUT J and HUGHES C (2017) Modelling potential hydrological returns from investing in ecological infrastructure: Case studies from the Baviaanskloof-Tsitsikamma and uMngeni catchments, South Africa. Ecosyst. Services. 27 261-271. https://doi.org/10.1016/j.ecoser.2017.03.003

MEDINA E, GARCIA V and CUEVAS E (1990) Sclerophylly and oligotrophic environments: relationships between leaf structure, mineral nutrient content, and drought resistance in tropical rain forests of the upper Rio Negro region. Biotropica 22 (1) 51-64. https://doi.org/10.2307/2388719

MEIJNINGER WML and JARMAIN C (2014) Satellite-based annual evaporation estimates of invasive alien plant species and native vegetation in South Africa. Water SA. 40 95-107. https://doi.org/ 10.4314/wsa.v40i1.12

MILLER JM, MILLER PC and MILLER PM (1984) Leaf conductance and xylem pressure potentials in Fynbos plant species. S. Afr. J. Sci. 80 381-385.

MOHAMED YA, BASTIAANSSEN WGM, SAVENIJE HHG VAN DEN HURK BJJM and FINLAYSON CM (2012) Wetland versus open water evaporation: An analysis and literature review. Phys. Chem. Earth. 47-48 114-121. https://doi.org/10.1016/j.pce.2011.08.005

MOONEY HA, FIELD C, GULOMAN SL, RUNDEL P and KRUGER FJ (1983) Photosynthetic characteristic of South African sclerophylls. Oecologia. 58 398-401. https://doi.org/10.1007/BF00385242

PICKARD WF (1982) Why is the substomatal chamber as large as it is? Plant Physiol. 69 971-974. https://doi.org/10.1104/pp.69.4.971

RAMATSABANA P, TANNER J, MANTEL S, PALMER A and EZENNE G (2019) Evaluation of remote-sensing based estimates of actual evapotranspiration over (diverse shape and sized) Palmiet wetlands. Geosciences 9 (491) 1-17. https://doi.org/10.3390/geosciences9120491

REBELO AJ (2012) An ecological and hydrological evaluation of the effects of restoration on ecosystem services in the Kromme River System, South Africa. MSc thesis, Stellenbosch University.

REBELO AJ (2017) Ecosystem services of Palmiet wetlands: The role of ecosystem composition and function. PhD thesis, University of Antwerp and Stellenbosch University.

SAVAGE MJ, ODHIAMBO GO, MENGISTU MG, EVERSON CS and JARMAIN C (2010) Measurement of grassland evaporation using a surface-layer scintillometer. Water SA. 36 (1) 1-8. https://doi.org/ 10.4314/wsa.v36i1.50901

SCHULZE RE (1995) Hydrology and agrohydrology: a text to accompany the ACRU 3.00 Agrohydrological Modelling System. WRC Report No. TT 95/69. Water Research Commission, Pretoria. $552 \mathrm{pp}$. 
SCOTT DF (1999) Managing riparian zone vegetation to sustain streamflow: results of paired catchment experiments in South Africa. Can. J. For. Res. 29 1149-1157. https://doi.org/10.1139/x99042

SEYHAN E, HOPE AS and SCHULZE RE (1983) Estimation of streamflow loss by evapotranspiration from a riparian zone. S. Afr. J. Sci. 79 88-90.

SINGELS A, JARMAIN C, BASTIDAS-OBANDO E, OLIVIER FC and PARASKEVOPOULOS AL (2018) Monitoring water use efficiency of irrigated sugarcane production in Mpumalanga, South Africa, using SEBAL. Water SA. 44 (4) 636-646. https://doi.org/10.4314/wsa. v44i4.12
SPECHT RL (1988) Foliar analyses. In: Specht RL (ed.) MediterraneanType Ecosystems. Springer, Netherlands. 63-80. https://doi.org/10. 1007/978-94-009-3099-5_3

VON WILLERT DJ, HERPPICH M and MILLER JM (1989) Photosynthetic characteristic and leaf water relations of mountain Fynbos vegetation in the Cedarberg area (South Africa). S. Afr. J. Bot. 55 (3) 288-298. https://doi.org/10.1016/S0254-6299(16)31178-4

WHITEHEAD D (1997) Regulation of stomatal conductance and transpiration in forest canopies. Tree Physiol. 18 633-644. https:// doi.org/10.1093/treephys/18.8-9.633 
APPENDIX

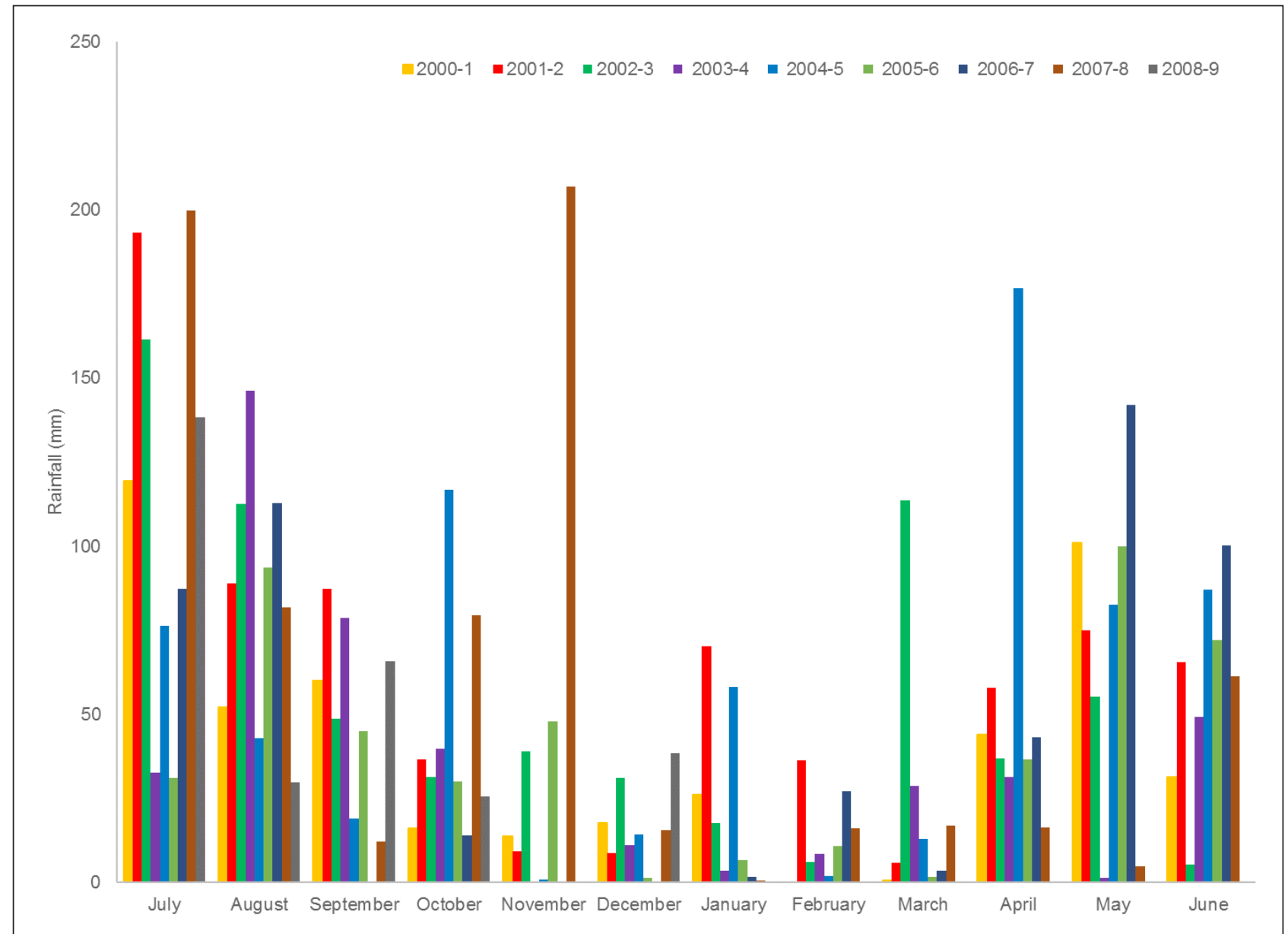

Figure A1. Mean monthly rainfall from the Villiersdorp weather station from 2000-2009, showing inter-annual variability and intra-annual patterns 


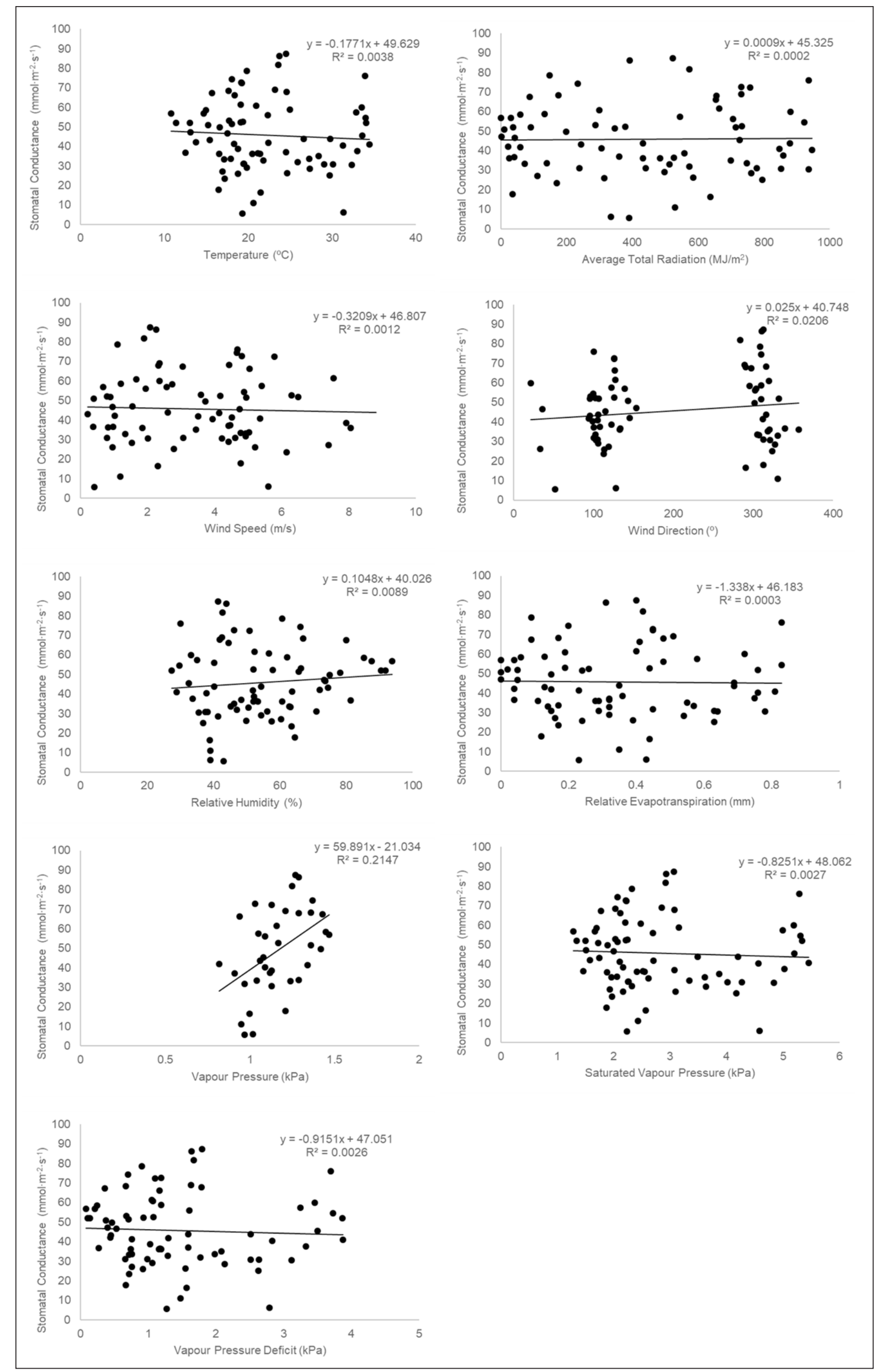

Figure A2. Correlations between field-measured stomatal conductance and climate variables taken from the South African Weather Service station at Swartboskloof 


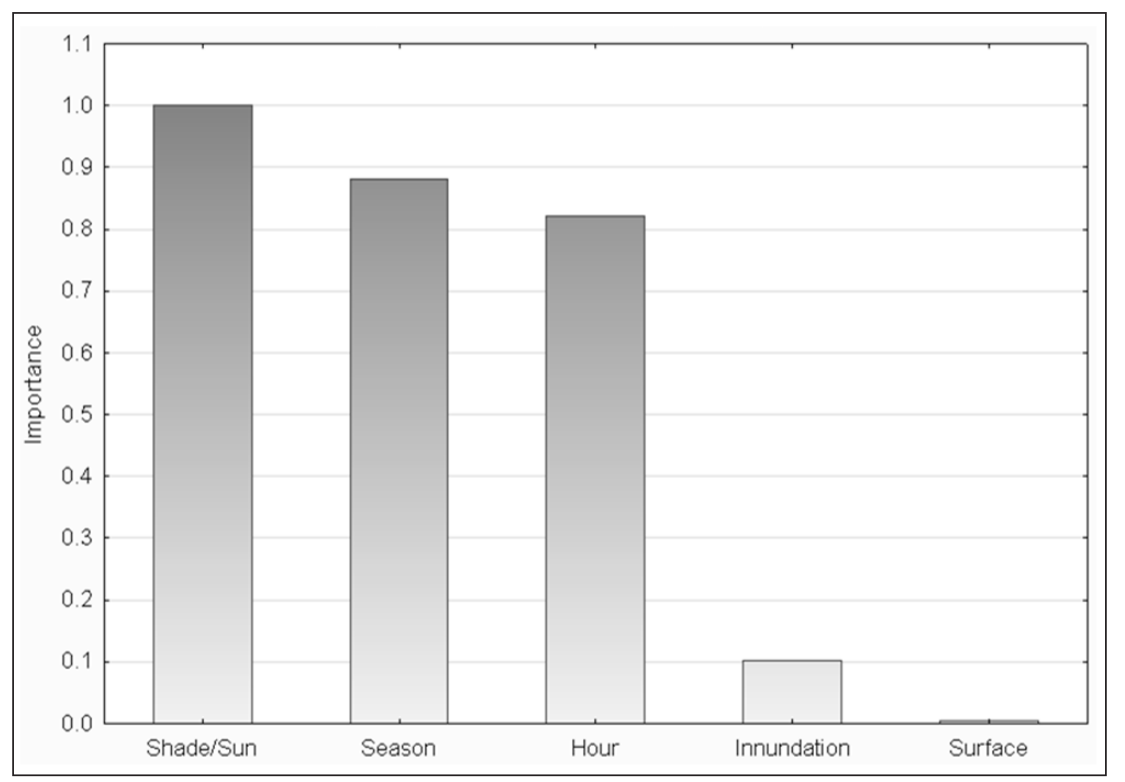

Figure A3. The relative importance of each of five variables on the stomatal conductance of Palmiet (Prionium serratum) in Jonkershoek, Western Cape using a CART Analysis

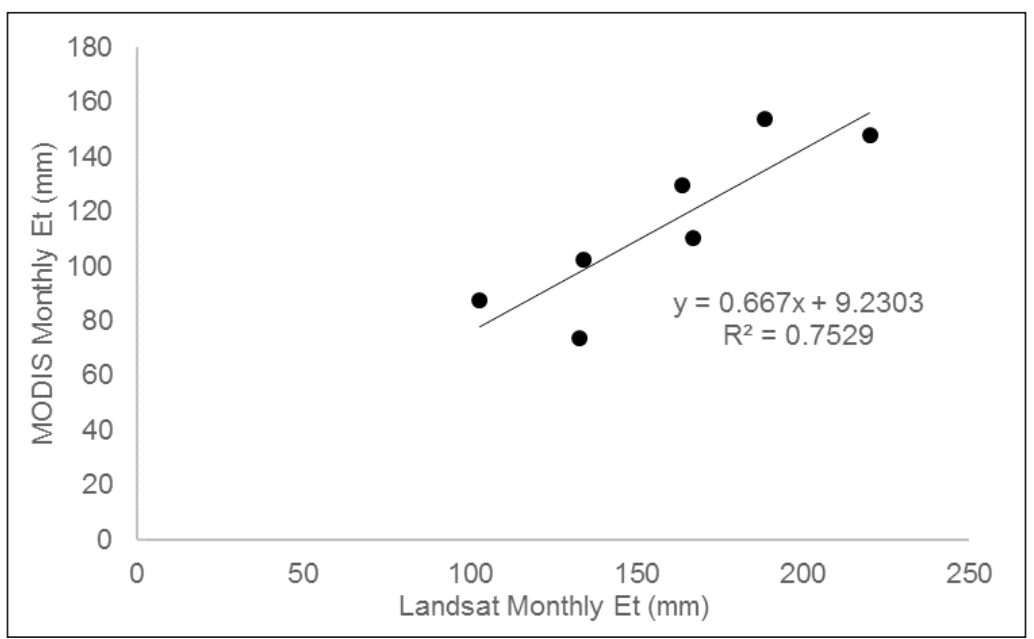

Figure A4. Correlation between the modelled monthly Landsat7-SEBAL and MODIS-SEBAL results for evapotranspiration of Palmiet: $R^{2}=0.7529$; $r=0.8677$

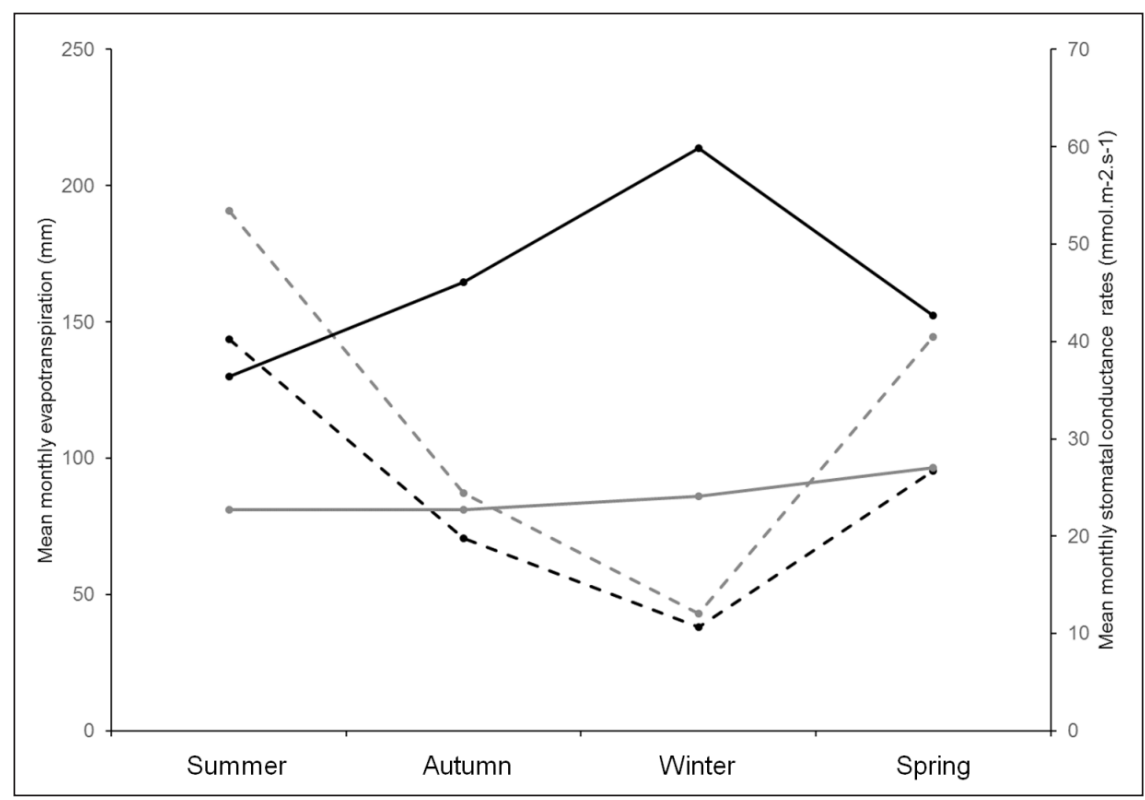

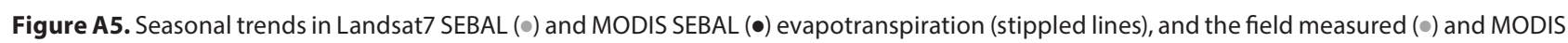
SEBAL $(\bullet)$ stomatal conductance (solid lines) 


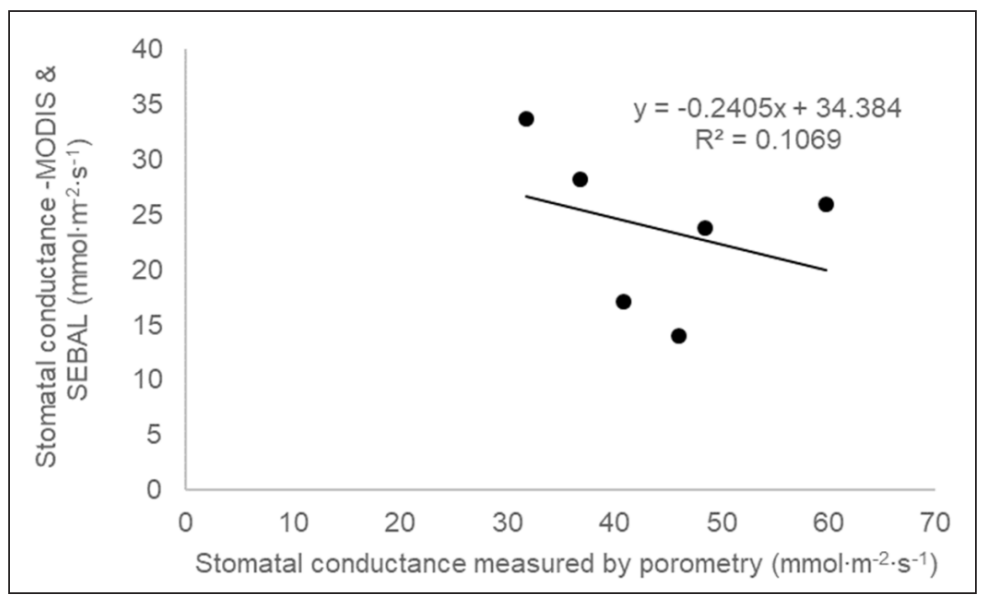

Figure A6. Correlation between monthly field measured stomatal conductance and modelled stomatal conductance from the SEBAL model (using MODIS imagery): $R^{2}=0.1069 ; r=0.3270$

Table A1. Summary statistics for monthly MODIS SEBAL evapotranspiration (all units as $\mathrm{mm} / \mathrm{month}$ ) per scene showing the year, month and seasons sampled; 6 images out of 36 were excluded due to cloud cover. Data were obtained from the research by Meijninger and Jarmain (2014)

\begin{tabular}{|c|c|c|c|c|c|c|c|c|}
\hline Year & Month & Season & Clouds & Min & Max & Range & Mean & Std dev \\
\hline 2000 & 07 & Winter & Cloud & & & & & \\
\hline 2000 & 08 & Winter & Cloud & & & & & \\
\hline 2000 & 09 & Spring & 0 & 59.01 & 70.38 & 11.38 & 66.54 & 3.45 \\
\hline 2000 & 10 & Spring & 0 & 134.71 & 154.88 & 20.17 & 147.24 & 6.27 \\
\hline 2000 & 11 & Spring & 0 & 104.84 & 118.57 & 13.74 & 111.79 & 4.71 \\
\hline 2000 & 12 & Summer & 0 & 135.97 & 162.91 & 26.94 & 149.14 & 8.75 \\
\hline 2001 & 01 & Summer & 0 & 125.45 & 147.14 & 21.69 & 135.55 & 7.32 \\
\hline 2001 & 02 & Summer & 0 & 110.91 & 122.80 & 11.89 & 116.63 & 3.65 \\
\hline 2001 & 03 & Autumn & 0 & 81.45 & 99.46 & 18.01 & 91.52 & 5.10 \\
\hline 2001 & 04 & Autumn & Cloud & & & & & \\
\hline 2001 & 05 & Autumn & 0 & 25.90 & 37.60 & 11.70 & 32.87 & 3.23 \\
\hline 2001 & 06 & Winter & 0 & 18.91 & 37.92 & 19.01 & 29.43 & 5.32 \\
\hline 2002 & 07 & Winter & 0 & 25.66 & 41.05 & 15.39 & 35.58 & 4.40 \\
\hline 2002 & 08 & Winter & 0 & 41.51 & 59.18 & 17.67 & 53.13 & 4.73 \\
\hline 2002 & 09 & Spring & Cloud & & & & & \\
\hline 2002 & 10 & Spring & 0 & 63.48 & 70.89 & 7.42 & 68.39 & 2.24 \\
\hline 2002 & 11 & Spring & 0 & 101.94 & 111.50 & 9.56 & 108.78 & 2.85 \\
\hline 2002 & 12 & Summer & Cloud & & & & & \\
\hline 2003 & 01 & Summer & 0 & 146.87 & 165.86 & 18.98 & 160.04 & 5.19 \\
\hline 2003 & 02 & Summer & 0 & 128.11 & 142.79 & 14.67 & 137.00 & 4.18 \\
\hline 2003 & 03 & Autumn & 0 & 71.02 & 85.22 & 14.20 & 80.45 & 4.29 \\
\hline 2003 & 04 & Autumn & 0 & 72.32 & 87.66 & 15.33 & 80.94 & 4.34 \\
\hline 2003 & 05 & Autumn & 0 & 29.46 & 44.71 & 15.25 & 38.84 & 4.25 \\
\hline 2003 & 06 & Winter & 0 & 22.01 & 43.30 & 21.29 & 35.12 & 6.08 \\
\hline 2006 & 07 & Winter & 0 & 16.54 & 28.13 & 11.59 & 23.61 & 3.26 \\
\hline 2006 & 08 & Winter & 0 & 33.77 & 43.13 & 9.37 & 39.41 & 2.72 \\
\hline 2006 & 09 & Spring & 0 & 69.82 & 86.15 & 16.33 & 80.48 & 4.44 \\
\hline 2006 & 10 & Spring & 0 & 87.94 & 93.26 & 5.32 & 91.07 & 1.77 \\
\hline 2006 & 11 & Spring & Cloud & & & & & \\
\hline 2006 & 12 & Summer & 0 & 139.74 & 150.45 & 10.71 & 146.17 & 3.35 \\
\hline 2007 & 01 & Summer & 0 & 161.72 & 167.36 & 5.64 & 165.21 & 1.82 \\
\hline 2007 & 02 & Summer & 0 & 126.31 & 137.67 & 11.36 & 134.79 & 3.48 \\
\hline 2007 & 03 & Autumn & 0 & 78.69 & 96.50 & 17.81 & 91.03 & 4.93 \\
\hline 2007 & 04 & Autumn & 0 & 72.78 & 86.13 & 13.36 & 81.60 & 3.89 \\
\hline 2007 & 05 & Autumn & 0 & 43.11 & 66.73 & 23.62 & 58.45 & 6.24 \\
\hline 2007 & 06 & Winter & 0 & 36.33 & 55.15 & 18.82 & 49.45 & 5.02 \\
\hline
\end{tabular}


Table A2. Summary statistics for monthly Landsat7 SEBAL evapotranspiration (all units as mm/month or for 2 months depending on the number of scenes used) per scene showing the year, month and seasons sampled. Data were obtained from the research by Klaasse et al. (2008)

\begin{tabular}{|c|c|c|c|c|c|c|c|c|c|c|c|}
\hline \multicolumn{3}{|c|}{ Image date } & \multirow{2}{*}{$\frac{\text { SEBAL period }}{\text { Day/month }}$} & \multirow[b]{2}{*}{ Season } & \multirow[b]{2}{*}{$\begin{array}{l}\text { Number } \\
\text { of scenes }\end{array}$} & \multicolumn{6}{|c|}{ Evapotranspiration per time period $(\mathrm{mm})$} \\
\hline Year & Month & Day & & & & Min & Max & Range & $\begin{array}{l}\text { Mean for all } \\
\text { scenes }\end{array}$ & Mean & Std dev \\
\hline 2004 & 09 & 20 & 09/2004 & Spring & 1 & 65.06 & 127.96 & 62.90 & 104.35 & 104.35 & 13.45 \\
\hline 2004 & 10 & 22 & $10 / 2004$ & Spring & 1 & 86.72 & 174.80 & 88.08 & 133.95 & 133.95 & 14.94 \\
\hline 2004 & 11 & 15 & $11 / 2004$ & Spring & 1 & 170.37 & 234.93 & 64.56 & 204.65 & 204.65 & 8.67 \\
\hline 2004 & 12 & 09 & $12 / 2004$ & Summer & 1 & 184.07 & 257.48 & 73.41 & 220.20 & 220.20 & 13.43 \\
\hline 2005 & 01 & 18 & $01 / 2005$ & Summer & 1 & 121.29 & 228.19 & 106.90 & 192.25 & 192.25 & 15.90 \\
\hline 2005 & 02 & 27 & $02 / 2005$ & Summer & 1 & 134.07 & 189.06 & 54.99 & 163.91 & 163.91 & 10.94 \\
\hline 2005 & 03 & 23 & $03-04 / 2005$ & Autumn & 2 & 88.69 & 248.83 & 160.14 & 173.25 & 86.63 & 25.69 \\
\hline 2005 & 10 & 09 & 09-10/2005 & Spring & 2 & 247.12 & 352.46 & 105.34 & 306.43 & 153.22 & 28.21 \\
\hline 2005 & 12 & 04 & $11 / 2005$ & Spring & 1 & 107.90 & 199.87 & 91.96 & 165.98 & 165.98 & 12.57 \\
\hline 2005 & 12 & 20 & $12 / 2005$ & Summer & 1 & 160.53 & 290.42 & 129.89 & 250.42 & 250.42 & 17.07 \\
\hline 2006 & 02 & 06 & $01-02 / 2005$ & Summer & 2 & 207.63 & 407.84 & 200.21 & 329.59 & 164.80 & 34.21 \\
\hline 2006 & 03 & 10 & $03-04 / 2005$ & Autumn & 2 & 166.31 & 310.67 & 144.37 & 262.26 & 131.13 & 17.98 \\
\hline 2006 & 10 & 12 & $09-10 / 2006$ & Spring & 2 & 231.25 & 319.00 & 87.75 & 281.34 & 140.67 & 15.88 \\
\hline 2006 & 10 & 28 & $11 / 2006$ & Spring & 1 & 85.75 & 149.36 & 63.61 & 130.07 & 130.07 & 9.26 \\
\hline 2006 & 12 & 23 & $12 / 2006$ & Summer & 1 & 154.16 & 206.99 & 52.83 & 190.03 & 190.03 & 8.77 \\
\hline 2007 & 02 & 17 & $01-02 / 2007$ & Summer & 2 & 366.12 & 451.32 & 85.21 & 417.56 & 208.78 & 15.72 \\
\hline 2007 & 03 & $13 / 29$ & $03-04 / 2007$ & Autumn & 2 & 172.52 & 219.06 & 46.54 & 181.86 & 90.93 & 6.14 \\
\hline
\end{tabular}

Table A3. One-way analysis of variance (ANOVA) Statistics.

Significance is denoted by *

\begin{tabular}{lccccc}
\hline ANOVA & DFn & DFd & $\mathbf{F}$ & $\mathbf{p}$ & ges \\
\hline Inundation & 1 & 1815 & 0.133 & 0.716 & $7.3 \times 10^{-5}$ \\
Surface & 1 & 1815 & 0.409 & 0.523 & 0.000225 \\
Light & 3 & 1813 & 24.892 & $8.81 \times 10^{-16 *}$ & 0.04 \\
\hline
\end{tabular}

Table A4. Posthoc analysis of variance (ANOVA) statistics to understand the significance of differences among light levels. Significance is denoted by: $0 * * * * 0.001 * 0.01 * 0.05$. ns: not significant

\begin{tabular}{|c|c|c|c|c|c|c|c|c|}
\hline & group1 & group2 & $\mathrm{n} 1$ & $\mathrm{n} 2$ & $p$ & $P$ sign. & $P$ adjusted & $P$ adjusted sign. \\
\hline 1 & Cloud & Shade & 278 & 1150 & 0.053 & ns & 0.320 & ns \\
\hline 2 & Cloud & Sun & 278 & 382 & 0.004 & $* *$ & 0.025 & * \\
\hline 3 & Cloud & Sunset & 278 & 56 & $8.44 \times 10^{-17}$ & $* * * *$ & $5.07 \times 10^{-16}$ & $* * * *$ \\
\hline 4 & Shade & Sun & 1150 & 382 & 0.096 & ns & 0.574 & ns \\
\hline 5 & Shade & Sunset & 1150 & 56 & $1.01 \times 10^{-15}$ & $* * * *$ & $6.06 \times 10^{-15}$ & $* * * *$ \\
\hline 6 & Sun & Sunset & 382 & 56 & $2.39 \times 10^{-12}$ & $* * * *$ & $1.43 \times 10^{-11}$ & $* * * *$ \\
\hline
\end{tabular}

Table A5. Statistical results of repeated-measures analysis of variance (AVOVA) in comparing the effects of season and time, as well as the interaction between them. Significance is denoted by: $0 * * * 0.001 * 0.01 * 0.05$. ns: not significant

\begin{tabular}{lcccccc}
\hline Parameter & Df & Sum sq & Mean sq & F value & Pr $(>$ F $)$ & Significance \\
\hline Season & 2 & 81409 & 40705 & 60.12 & $<2 \times 10^{-16}$ & $* * *$ \\
Time & 12 & 177270 & 14773 & 21.82 & $<2 \times 10^{-16}$ & $* * *$ \\
Season:Time & 15 & 130789 & 8719 & 12.88 & $<2 \times 10^{-16}$ & $* * *$ \\
Residuals & 1770 & 1198318 & 677 & & & \\
\hline
\end{tabular}


Table A6. Statistics comparing the significance of including various fixed effects in predicting stomatal conductance. The model included fixed (season, time, light, inundation, leaf surface), random (date, plant) and interaction effects (season:time, time:light) of Palmiet wetland stomatal conductance. The F-test with Kenward-Roger approximation was used to make comparisons between models. Significance is denoted by: 0 *** $0.001 * * 0.01 * 0.05$.

\begin{tabular}{|c|c|c|c|c|c|}
\hline F Test & F Statistic & ndf & ddf & F Scaling & $p$ value \\
\hline Season & 5.54 & 17.00 & 156.28 & 0.96 & $1.264 \times 10^{-9 * * *}$ \\
\hline Time & 14.66 & 46.00 & 1739.38 & 1.00 & $<2.2 \times 10^{-16 * * *}$ \\
\hline Light & 11.25 & 22.00 & 1476.23 & 1.00 & $<2.2 \times 10^{-16 * * *}$ \\
\hline Inundation & 0.28 & 1.00 & 4.01 & 1.00 & 0.6272 \\
\hline Leaf surface & 2.96 & 1.00 & 1754.09 & 1.00 & 0.08549 \\
\hline
\end{tabular}

Table A7. Total monthly A-Pan evaporation $(\mathrm{mm})$ from the Villiersdorp weather station (South African Weather Service). Mean annual A-Pan evaporation for all years was $2809 \mathrm{~mm} \cdot \mathrm{a}^{-1}$.

\begin{tabular}{|c|c|c|c|c|c|c|c|c|c|c|c|c|c|c|c|c|}
\hline & 1990 & 1991 & 1992 & 1993 & 1994 & 1995 & 1996 & 1997 & 1998 & 1999 & 2000 & 2001 & 2002 & 2003 & 2004 & 2005 \\
\hline January & 431.9 & 389.3 & 429.4 & 452.2 & 389.0 & 422.1 & 351.6 & 389.0 & 409.0 & 382.6 & 357.9 & 409.1 & 351.8 & 428.9 & 300.7 & 354.9 \\
\hline February & 349.8 & 330.1 & 329.8 & 364.0 & 313.1 & 367.0 & 364.7 & 309.9 & 341.7 & 354.1 & 348.4 & 335.4 & 323.1 & 344.2 & 281.7 & 305.2 \\
\hline March & 267.5 & 323.9 & 302.7 & 291.4 & 293.0 & 273.6 & 291.5 & 278.0 & 268.7 & 326.8 & 239.8 & 244.5 & 302.9 & 304.3 & 261.5 & 284.6 \\
\hline April & 189.6 & 221.6 & 198.2 & 106.3 & 191.4 & 183.2 & 222.5 & 142.5 & 173.2 & 212.0 & 145.0 & 149.0 & 197.1 & 186.9 & 171.7 & 136.5 \\
\hline May & 100.1 & 142.9 & 106.3 & 78.4 & 99.8 & 112.2 & 128.4 & 154.0 & 93.5 & 113.4 & 101.9 & 173.3 & 123.3 & 118.2 & 159.8 & 110.2 \\
\hline June & 72.9 & 106.4 & 84.0 & 72.9 & 81.4 & 102.5 & 120.7 & 75.1 & 97.0 & 137.6 & 108.3 & 104.9 & 97.6 & 106.0 & 145.4 & 71.0 \\
\hline July & 107.4 & 97.2 & 115.7 & 123.1 & 80.0 & 109.4 & 86.4 & 120.2 & 107.6 & 129.4 & 88.0 & 116.4 & 90.6 & 175.7 & 93.3 & 108.2 \\
\hline August & 137.2 & 131.7 & 117.7 & 125.5 & 105.9 & 130.7 & 123.9 & 104.2 & 142.9 & 137.6 & 125.5 & 143.5 & 151.2 & 148.7 & 116.4 & 58.0 \\
\hline September & 209.9 & 156.2 & 151.5 & 171.9 & 192.0 & 176.0 & 171.6 & 201.7 & 200.2 & 133.1 & 189.9 & 183.0 & 200.2 & 188.8 & 210.9 & 138.8 \\
\hline October & 290.8 & 205.4 & 231.0 & 305.7 & 305.3 & 268.3 & 208.2 & 341.8 & 318.7 & 270.4 & 250.2 & 242.4 & 318.5 & 300.2 & 283.1 & 185.3 \\
\hline November & 325.3 & 342.3 & 350.5 & 361.4 & 378.9 & 306.5 & 261.5 & 307.3 & 308.4 & 322.3 & 359.6 & 351.1 & 383.2 & 335.6 & 331.3 & 305.0 \\
\hline December & 420.6 & 428.0 & 430.0 & 384.5 & 388.5 & 300.1 & 364.0 & 408.0 & 353.6 & 411.3 & 360.6 & 391.9 & 424.4 & 319.9 & 424.8 & 354.5 \\
\hline TOTAL & 2903.09 & 2874.99 & 2846.69 & 2837.15 & 2818.23 & 2751.44 & 2694.9 & 2831.65 & 2814.57 & 2930.29 & 2675.12 & 2844.37 & 2963.69 & 2957.36 & 2780.34 & 2412.12 \\
\hline
\end{tabular}

Table A8. Total monthly reference evapotranspiration $(\mathrm{mm})$ from the Villiersdorp weather station (South African Weather Service). Mean annual reference evapotranspiration for all years was $1302 \mathrm{~mm} \cdot \mathrm{a}^{-1}$.

\begin{tabular}{lcccc}
\hline Month & $\mathbf{2 0 0 4}$ & $\mathbf{2 0 0 5}$ & $\mathbf{2 0 0 6}$ & $\mathbf{2 0 0 7}$ \\
\hline January & 139.8 & 131.4 & 122.5 & 166.5 \\
February & 117.3 & 125.4 & 112.8 & 157.9 \\
March & 92.1 & 106.6 & 103.2 & 142.3 \\
April & 81.0 & 78.3 & 85.8 & 99.3 \\
May & 75.3 & 73.8 & 74.7 & 90.2 \\
June & 58.8 & 58.5 & 66.3 & 64.2 \\
July & 67.9 & 61.7 & 74.7 & 75.3 \\
August & 86.2 & 96.4 & 85.6 & 98.3 \\
September & 116.7 & 122.4 & 123.9 & 124.8 \\
October & 133.6 & 127.1 & 134.2 & 102.9 \\
November & 145.5 & 150.6 & 133.5 & 136.8 \\
December & 135.8 & 163.4 & 146.9 & 140.7 \\
\hline TOTAL & 1249.97 & 1295.67 & 1264.17 & 1399.25 \\
\hline
\end{tabular}

